\title{
WNT2B wt Allele
}

National Cancer Institute

\section{Source}

National Cancer Institute. WNT2B wt Allele. NCI Thesaurus. Code C52993.

Human WNT 2B wild-type allele is located in the vicinity of 1 p13 and is approximately 56

$\mathrm{kb}$ in length. This allele, which encodes protein wnt-2b, plays a role in embryogenesis. 